\title{
Valuing Marine Biodiversity in the Gulf of Mexico: Evidence from the Proposed Boundary Expansion of the Flower Garden Banks National Marine Sanctuary
}

Stephanie F. Stefanski, Duke University; Jay P. Shimshack, University of Virginia

\begin{abstract}
A B S T R A C T
Ecological diversity is especially high in the Gulf of Mexico, and multiple Gulf of Mexico resources imply complex management challenges. Yet, relatively little is known about social values of marine biodiversity in the Gulf of Mexico. This article uses results from a stated preference survey of nationally representative households to quantify economic values. The specific assessment scenario involves a current policy proposal to expand the boundaries of the Flower Garden Banks National Marine Sanctuary. Willingness to pay estimates range from $\$ 35-\$ 107$ per household. Respondent characteristics are related to willingness to pay in ways consistent with economic intuition and theory. We conclude with aggregate willingness to pay calculations, and results suggest that total social benefits of marine reserve expansion in the Gulf region are large.
\end{abstract}

Key words: Marine biodiversity, Gulf of Mexico, national marine sanctuary.

JEL Codes: Q22, Q28, Q51.

\section{INTRODUCTION}

The Gulf of Mexico is a hub of marine biodiversity, commercial fishing, oil and gas exploration and drilling, and outdoor recreation. Managing multiple uses in the area is costly and controversial, and scholars and policymakers regularly debate the cost effectiveness of marine conservation and biodiversity protection (Coleman, Baker, and Koenig 2004; Cruz and McLaughlin 2008). Discussions of conservation costs focus on restrictions to commercial fishing and oil/gas sectors, administrative expenditures, and economic losses to local communities. Discussions of conservation benefits, however, are comparatively vague, as both use and non-use values for preserving marine biodiversity are difficult to measure. Balanced policy choices, however, require a more complete understanding of such benefits.

This study explores US residents' willingness to pay (WTP), a measure of social value, for marine protected areas in the Gulf of Mexico. We focus on marine conservation in the Gulf of Mexico for three reasons. First, ecological diversity there is especially high. A current census of

Stephanie F. Stefanski is a PhD student, Nicholas School of the Environment, Duke University, 9 Circuit Dr., Durham, NC 27708 USA (email: stephanie.stefanski@duke.edu). Jay P. Shimshack, Associate Professor of Public Policy and Economics, Frank Batten School, University of Virginia, 235 McCormick Rd., Charlottesville, VA 22904 USA (email: jay.shimshack@virginia.edu).

The authors thank Editor-in-Chief Martin Smith, an anonymous associate editor, three anonymous referees, Bob Leeworthy, G. P. Schmahl, the staff of the NOAA Office of Marine Sanctuaries, Quenton Dokken, the staff of the Gulf of Mexico Foundation, Timothy Beatty, Rob Mendelsohn, and Michael B. Ward for helpful discussions. The authors also thank Tulane University's Murphy Institute, Newcomb College, and Georges Lurcy program for generous support.

Received June 30, 2014; Accepted October 19, 2015; Published online January 20, 2016. http://dx.doi.org/10.1086/685109

Marine Resource Economics, volume 31, number 2. (c) 2016 MRE Foundation, Inc. All rights reserved. 0738-1360/2016/3102-000X\$10.00. 
global marine biodiversity ranked the Gulf of Mexico in the top five in both species per unit area and threats to species diversity (Costello et al. 2010). Second, Gulf Coast resources contribute to economic and cultural welfare. The National Oceanic and Atmospheric Administration (NOAA) estimates that Gulf Coast activities generate trillions of dollars in economic output and support millions of jobs annually (National Ocean Service 2011). Third, as highlighted by the 2010 Deepwater Horizon oil spill and its associated policy responses, the area faces difficult tradeoffs between resource extraction, commercial harvesting, and environmental preservation.

This article estimates WTP for marine protection in the Gulf of Mexico using a stated preference survey of over 1,500 nationally representative respondents. Our methods follow recommendations of the contemporary literature, as outlined in Arrow et al. (1993), Carson et al. (2003), Whitehead (2006), Kling, Phaneuf, and Zhao (2012) and Haab et al. (2013). We determine if respondents would vote for or against a hypothetical-yet realistic-environmental program. Our specific valuation scenario involves a proposed boundary expansion of the Flower Garden Banks National Marine Sanctuary. Our survey instrument was pre-tested and contains conservative design features. We employ several ex-post diagnostics and checks for understanding and internal consistency.

We find that the average respondent expressed a significantly positive WTP for expanding marine sanctuaries in the Gulf of Mexico. Empirical WTP estimates range from \$35-\$107 per household. Determinants of WTP are generally consistent with economic intuition and theory. Respondents were sensitive to scope. All key results are robust to several empirical specifications, multiple sampling choices, including or omitting likely protest no responses, and including or omitting responses with possible payment vehicle misunderstanding.

While we attempt no significant methodological contributions, we believe our analysis makes several contributions to economics and policy. First, we enumerate social values for marine resources. A large literature assesses WTP for conservation programs in terrestrial contexts, but fewer studies examine marine conservation. Marine biodiversity remains incompletely understood yet extraordinarily rich (Appletans et al. 2012). Second, we provide early evidence on WTP for marine reserves in the Gulf of Mexico. Our results are especially timely, as the scenario presented in our study is based directly on current policy proposals: NOAA's "Flower Garden Banks Boundary Expansion Recommendation" and NOAA's "Flower Garden Banks Final Management Plan” (US Department of Commerce 2012). Third, our analysis sample is large and nationally representative. We inform the national marine policy debate directly, as our analysis does not restrict itself to local residents or visitors only.

\section{BACKGROUND AND LITERATURE}

THE GULF OF MEXICO: A PRODUCTIVE MULTIPLE-USE RESOURCE

The Gulf of Mexico is a crucial center of economic activity. About 37\% of the population of Florida, Alabama, Mississippi, Louisiana, and Texas lives in the Gulf Coast region. Leading industries include oil and gas production, shipping, commercial fishing, tourism, and recreation. Between 2007 and 2009, approximately one-half of US crude oil and national gas production occurred in the Gulf Coast region. Approximately 50\% of US international trade tonnage passes through Gulf Coast ports every year. About one-sixth of US fishery landings between 2007 and 2009 were from the Gulf of Mexico, with menhaden, shrimp, oysters, and crab as the 
leading species. Tourism and recreation industries along the Gulf account for over 650,000 jobs and generate over $\$ 10$ billion in wages annually. ${ }^{1}$

These activities, however, have possible costs. The Gulf of Mexico is one of the world's top five most threatened marine ecosystems in terms of biodiversity (Costello et al. 2010). Ecologically productive and economically important wetlands continue a net decline throughout the region. Overfishing and bycatch may imperil the Gulf ecosystem (Ritchie and Keller 2008). Species of whales, turtles, fish, and seabirds are threatened or endangered. Nutrient and chemical pollution remain serious issues, and a hypoxic "dead zone" regularly exceeds 5,000 square miles (US EPA 2011).

\section{CURRENT AND PROPOSED MARINE SANCTUARIES IN THE GULF OF MEXICO}

Two marine sanctuaries in the Gulf protect coral reefs and related marine ecosystems. The Florida Keys sanctuary was designated in 1990, and is jointly administered by NOAA and the State of Florida. The sanctuary allows commercial and recreational fishing, although 24 no-take areas have significant restrictions. Non-consumptive recreational activities are allowed in all areas, except one area in the Tortugas Ecological Reserve 70 miles west of Key West. Oil and gas activities are prohibited throughout the reserve.

The Flower Garden Banks National Marine Sanctuary, located off the coasts of Texas and Louisiana, was established in 1992 and 1996. The total area of the sanctuary is about 56 square miles, and it is composed of three separate banks (East Flower Garden Bank, West Flower Garden Bank, and Stetson Bank). Protected banks include the northernmost coral reefs in the continental US and provide habitat for distinct biological communities. Flower Garden Banks regulations restrict commercial and recreational fishing to hook-and-line only. While approximately 150 oil and gas platforms operate within 25 miles of current sanctuary boundaries, only one platform operates within the sanctuary itself on a permit granted prior to the sanctuary's establishment (US Department of Commerce 2012).

The policy proposal in the stated preference survey that follows is based on a current proposal to expand the boundaries of the Flower Garden Banks sanctuary. A public review process of the sanctuary management plan, beginning in 2006 and continuing through 2012, identified significant threats to biological and geologic resources in the Flower Garden Banks area. The review also highlighted important links between existing sanctuary areas and nearby reefs. A NOAA advisory council recommended a boundary expansion of the existing sanctuary. Our valuation scenario emphasizes the council's recommendation to add nine additional banks to the sanctuary's three existing banks (US Department of Commerce 2012). Figure 1 shows current and proposed protected area boundaries. Oil and gas exploration, fishing activities, pollution releases, and anchoring activities would be closely regulated or prohibited in designated areas.

\section{RELATED LITERATURE}

Our goal of assessing public values for marine protected areas builds on a growing literature. Although we do not discuss every contribution, we highlight illustrative examples from a

1. All of the statistics in this paragraph are adopted from National Ocean Service (2011). 


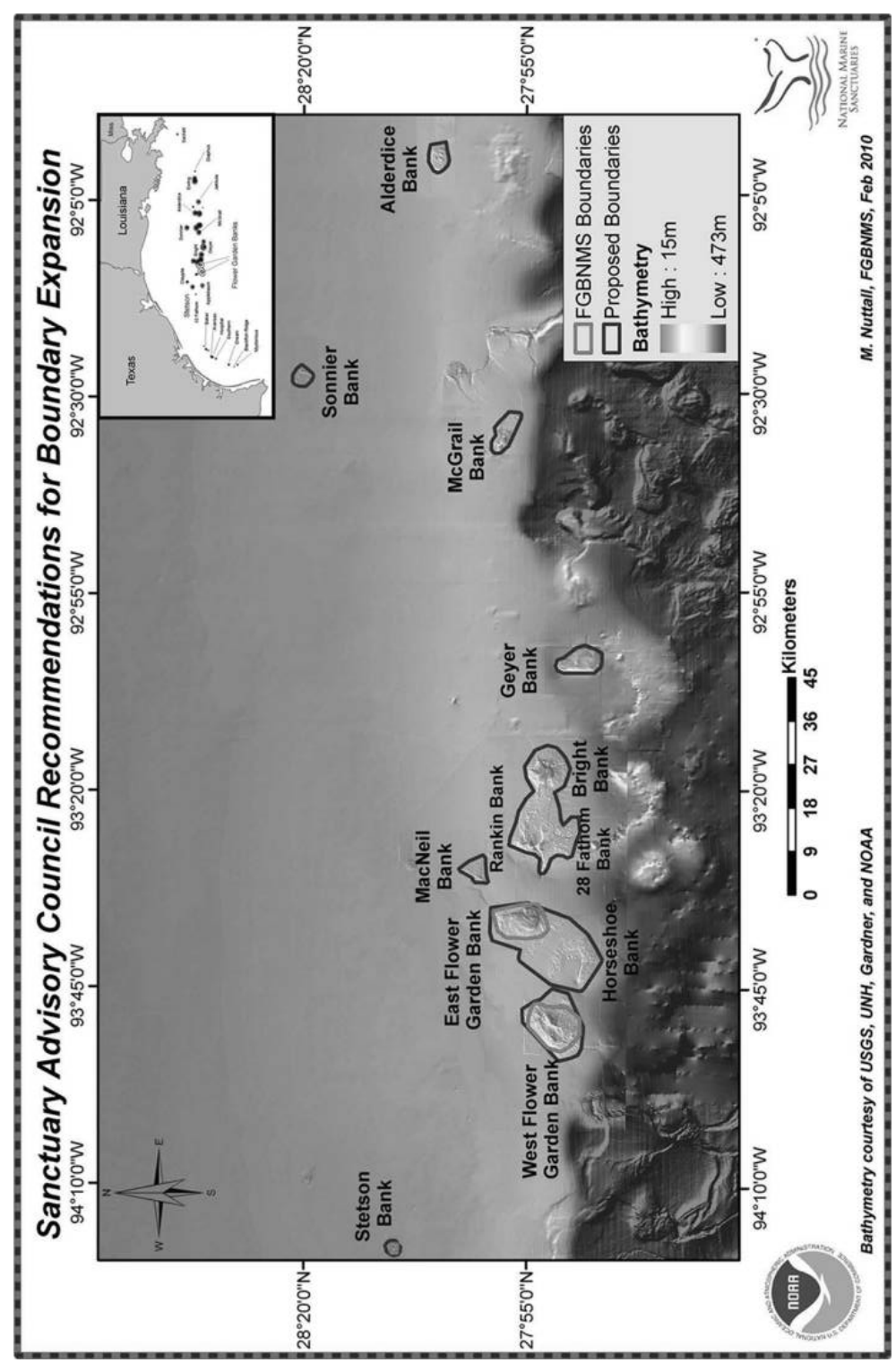

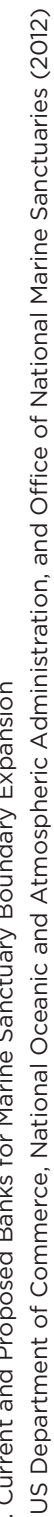

ํํำ 
variety of marine contexts. We first motivate the broader context for our study by noting that marine reserves are controversial due to the tradeoffs between extractive and non-extractive resource uses. Fisheries benefits and costs are often especially challenging. The benefits and costs of marine reserves for fisheries are not always directly observable and may vary significantly over time (Smith et al. 2010). In the short run, protected areas exclude fishermen from productive fishing grounds, and fishermen may perceive significant costs as a result (Gleason et al. 2013; Kahui and Alexander 2008; Suman, Shivlani, and Milon 1999). Over the longer run, marine reserves may increase overall fishery yields and aggregate biomass (Holland and Brazee 1996; Sanchirico and Wilen 2001). They may also buffer habitats against shocks, like pollution events (Barbier 2012). Nevertheless, the relevant state of knowledge is not definitive and may well be context dependent. One recent study of two Gulf of Mexico marine reserves failed to detect statistically significant impacts on reef fish harvest or production within four years of designation (Smith, Zhang, and Coleman 2007).

The present study builds most directly on research that explores WTP for marine reserves and reserve operations. Depondt and Green (2006), Peters and Hawkins (2009), Ransom and Mangi (2010), and Reid-Grant and Bhat (2009) explore public support for marine reserve financing mechanisms. Other authors directly assess WTP for marine reserves, parks, and conservation zones themselves outside of the US waters (Mathieu, Langford, and Kenyon 2003; Togridou, Horvadas, and Pantis 2006; McVittie and Moran 2010). Subade (2005) combined field interviews and mail surveys to explore values for the Philippines' Tubbataha Reefs National Marine Park. Ressurreição et al. (2011) explored values for biodiversity preservation in the open seas around the archipelago of the Azores. Studies generally find variable individual values for marine protection but significantly positive average WTP. Positive values were primarily motivated by recreation and passive use considerations.

Several recent studies investigated economic values for marine resources in the Caribbean. These studies are relevant for our study as the Gulf marine ecosystem shares similar characteristics with Caribbean destinations due to the inner-loop current. These studies generally find resource values in the range of $\$ 20$ to $\$ 40$, with some exceptions depending on payment vehicle and sampling method (Dixon, Scura, and van't Hof 1993; Schuhmann et al. 2013; Spash 2002; Thur 2010; Uyarra, Gill, and Cote 2010). Spash (2002) assessed willingness to contribute to a trust fund for two different marine protected areas in Jamaica and Curacao. In both areas, locals and tourists expressed a WTP of about $\$ 25$ towards the fund. ${ }^{2}$

In the study perhaps most closely related to our own, Bishop et al. (2011) explored the value of increasing the size of no-fishing zones around the main Hawaiian Islands from the current 1 to $25 \%$. Bishop et al. (2011) also solicited respondents' WTP to restore damaged

2. Several authors have explored valuation of marine and coastal ecosystem services-rather than marine reserves-in the US. Barbier (2012) reviews the broader literature, and the Hall, Hall, and Murray (2002) survey of visitors to Southern California beaches to determine WTP to prevent further degradation of protected rocky intertidal zones is an illustrative example. Some of this research relates directly to the Gulf of Mexico context. Landry et al. (2011) found that New Orleans residents expressed positive WTP to restore the city's storm defenses, including the restoration of natural storm protection, such as wetlands and barrier islands. Petrolia and Kim $(2009,2011)$ studied Mississippi and Louisiana residents' WTP to restore barrier islands and prevent wetlands losses. Kim, Petrolia, and Interis (2012) applied a new "quasi-double-referendum (QDR)" valuation technique to barrier island restoration in Mississippi. Finally, Petrolia, Interis, and Hwang (2014) conducted a nationwide survey to assess welfare benefits of wetland restoration in coastal Louisiana; respondents reported an average WTP a one-time tax of $\$ 909$ per household. 
reefs. The authors found that increasing marine protected areas around the main Hawaiian Islands was worth about $\$ 225$ per year to the average US household. Repairing five acres of reefs per year after ship strikes was worth an incremental $\$ 63$ per year to the average household.

\section{METHODS AND DATA}

QUESTIONNAIRE DESIGN

Our survey's introduction served as a consent form for participation in the survey but did not disclose the specific purpose of the research. ${ }^{3}$ The main portion of the survey followed the Carson et al. (2003) Exxon Valdez survey instrument, as well as the recommendations of Arrow et al. (1993) and Whitehead (2006). The first section collected data on respondents' preferences for different social and environmental issues. The second section provided background information on marine biodiversity and coral habitats in the Gulf of Mexico. The third section presented the valuation scenario, elicited WTP, and explored choice motivations. The final sections debriefed respondents and collected socio-demographic information.

After general attitudinal questions, the early part of the survey instrument provided information on the Gulf of Mexico, marine habitat biodiversity, and threats to marine ecosystems. Detailed information establishes familiarity with the good being provided and allows respondents to understand exactly what they would be paying for (Carson, Flores, and Meade 2001). All facts, concepts, and questions were presented in simple language. To enhance respondents' understanding and to maintain their interest, photographs, maps, and questions were included. The central part of the survey instrument described the concept of marine protected areas and the characteristics of the two current marine sanctuaries in the Gulf of Mexico. This section included questions about familiarity and visitation. Respondents were given the option to read additional information on coral habitats in the Gulf of Mexico, if desired.

The survey's valuation scenario described a new marine sanctuary program. As noted in the background section, above, the presented program was based on a policy proposal to expand the boundaries of Flower Garden Banks National Marine Sanctuary. The program included adding nine protected banks to the current three protected banks. The program also included a specific enforcement plan consisting of a full-time monitoring vessel. Respondents were told the program would be jointly paid for by companies operating in the Gulf and households like theirs. The exact payment vehicle was a special annual tax added to federal income taxes at the end of each year. The survey outlined both benefits and costs of marine protected areas, and respondents were given reasons to vote for the program and reasons to vote against the program. This material followed the Carson et al. (2003) Exxon Valdez survey closely.

The questionnaire then elicited value preferences with double-bounded dichotomous choice (DBDC) questions. We asked respondents, "government officials estimate that the program will cost your household a total of $\$ X$. . . This money would only be used for the program to manage and enforce the regulations of the sanctuary. If the program cost your household a total of $\$ X$ at the end of the year, would you vote for the program or against it?" Initial costs $\$ \mathrm{X}$ were specified randomly across five different final questionnaire versions, with possible values $\$ \mathrm{X}$ equal to $\$ 4, \$ 10, \$ 20, \$ 40$, and $\$ 80$. This specific range of values was derived from extensive

3. The survey was reviewed by the authors' Institutional Review Board to ensure the protection of human subjects. 
survey pre-testing with open-ended questions, so that the bid distribution covered the bulk of the likely population distribution of WTP.

If the respondent initially voted for the program given a randomly assigned cost $\$ \mathrm{X}$, the respondent was then asked, "You stated that you would be willing to pay $\$ X$ at the end of each year in order to contribute towards the program. If the program cost your household $\$ 2 X$ at the end of each year, would you vote for the program or against it?" If the respondent instead initially voted against the program given a randomly assigned cost $\$ \mathrm{X}$, the respondent was then asked, "What if the program cost your household a total of $\$ 1 / 2 X$ at the end of each year, would you vote for the program or against it?" Other than WTP questions, all survey versions were identical.

Later sections of the surveys elicited WTP motivations, debriefed respondents, and collected socio-demographic information. Respondents agreeing to vote for the program were asked questions designed to distinguish between use values, option values, and passive use values. Respondents voting against the program were asked questions designed to distinguish between "true zero values" and "protest no" responses. We then explored if respondents understood the market scenario or thought the program might be effective. This latter issue was addressed with a question asking, "If the marine sanctuary program was established, how effective do you think it would be in preventing further coral habitat degradation and biodiversity loss?" The survey concluded by soliciting information on gender, race, age, educational attainment, political affiliations, and income.

A sample survey is available as online Appendix B.

\section{HYPOTHETICAL BIAS AND CONSEQUENTIALITY}

Our survey attempts to minimize hypothetical bias. We provide a realistic, detailed scenario based on a real-world policy proposal. We offer the good of interest after asking respondents to think about paying for other public goods. Income and substitution effects imply that this procedure may conservatively lower stated WTP for the good of interest. We remind survey respondents of their budget constraint immediately prior to valuation questions. Following Carson et al. (2003), the survey notes that, "some people would vote for the program and others would vote against it. Both have good reasons for why they would vote that way. . . those who vote against the program mention concerns like: . . Paying for this program would mean they would have less money to use for other things that are more important to them. ... the money they would have to pay for the program is more than they can afford."

As with many related studies, consequentiality may pose potential threats to internal validity (Haab et al. 2013; Hwang, Petrolia, and Interis 2014). Our scenario is based on reserve expansion rather than new creation, so respondents may plausibly believe the program is implementable. We expect respondents to view our survey as advisory, as it was actually designed, in part, for that purpose. Carson and Groves (2007, 2011), Johnston (2006), and Vossler and Poe (2011) provide evidence that results from advisory contingent valuation studies can be predictive of results from real referendums under reasonable conditions. Our income tax payment mechanism strikes a reasonable balance. The most natural alternative, an entrance fee, is not practical for a marine sanctuary where access restriction is essentially impossible and where recreation may represent a small portion of total value. Voluntary payment options are also poor choices, as they may be less incentive compatible and may encourage free riding (Ivehammer 2009; Vossler and Poe 2011). Respondents are likely to believe 
income taxes are collectible. Actual financial referendums and tax provisions regularly involve habitat protection and conservation funds and programs, as well as tax credits for select environmental and energy issues. We focus on federal income taxes rather than state or local taxes since our program was national in scope and many states (including large Gulf States like FL and TX) have no state income tax. ${ }^{4}$

\section{SURVEY IMPLEMENTATION}

The survey instrument was developed and disseminated in three phases spanning June 2011 to May 2012. Phase 1 involved preliminary survey development. Phase 2, conducted with contracted partner Qualtrics Software, involved pre-testing the survey online. Versions of the survey were distributed to more than 100 targeted respondents. Targeted respondents included environmental economists, biodiversity experts, students, and a variety of marine policy stakeholders in the Gulf Coast region. Pre-testing emphasized plausibility, scientific accuracy, policy accuracy, clarity, and flow. Single open-ended WTP questions also informed initial program cost offers for the five later versions of the final survey instrument. In May 2012, the Phase 3 final survey instrument was distributed online to a nationally representative general population panel managed by market research companies Qualtrics and ClearVoiceSurveys.com.

While the NOAA panel (Arrow et al. 1993) did not evaluate online survey methods, we opted to conduct an online survey due to comparative advantages over other survey methods. Online surveys are an inexpensive way to obtain representative samples. They can be implemented quickly for policy-relevant topics like ours. Online surveys may reduce "yeah-saying," social desirability bias, and other interviewer biases highlighted in Clark, Burgess, and Harrison (2000) and Börger (2013). However, internet surveys may increase sampling error, non-response bias, and measurement error. Approximately $20 \%$ of the US population does not regularly use the internet (Internet World Stats 2011). Selection bias can also occur if participants opt out of surveys in progress, perhaps due to disinterest or lack of time (Thurston 2006). Reassuringly, however, recent studies suggest that the average WTP of internet surveys is similar to that of a face-to-face and telephone surveys, at least in high-income counties. See Lindhjem and Navrud (2011), Nielsen (2011), and their citations for detail.

\section{CHARACTERISTICS OF THE FINAL SAMPLE}

A panel of 2,183 individuals identified as nationally representative by our contracted partner Qualtrics started the survey. A total of 1,867 respondents reached the end of the survey, and 1,550 of these individuals completely answered all WTP questions. Nine surveys had missing demographics, two had missing attitudinal responses, and 13 had other missing information. Our final effective sample was 1,526 respondents, which represents a $69.9 \%$ full completion rate. ${ }^{5}$

Table 1 reviews our sample composition. Overall, sample characteristics are generally consistent with national demographics. Our sample has slight overrepresentations of white

4. Directly asking respondents about consequentiality issues could have provided valuable additional information. For example, Petrolia, Interis, and Hwang (2014) asked respondents 'how important did you think your vote would be . . " and "do you think the results of this survey will shape the direction of future policy . . ." Similarly, Johnson et al. (2012) asked respondents how likely they would be to vote for the program if it were really put to a referendum.

5. Our contract with Qualtrics required delivery of a sample of 1,000 representative respondents. This subsample had similar demographic characteristics and generated extremely similar key results (signs, magnitudes, significance) as our full sample. We use the full sample of 1,526 respondents, which affords us more statistical power. 
Table 1. Sample Composition

\begin{tabular}{lcc}
\hline Characteristic & Our Sample $(\mathrm{N}=1526)(\%)$ & US Population (\%) \\
\hline Gender: Female & 50.7 & 50.8 \\
Origin: Hispanic & 14.7 & 16.3 \\
Race: White & 81.2 & 78.3 \\
Race: Black & 11.5 & 13.0 \\
Race: Asian & 6.2 & 4.9 \\
Age: $18-44$ & 45.3 & 48.1 \\
Age: 45 and older & 54.7 & 51.9 \\
Educ: Bachelor's Deg. or Higher & 34.1 & 28.2 \\
Party: Identify as Democrat & 36.4 & 31.0 \\
HH Income: $<\$ 20,000$ & 19.2 & 19.2 \\
HH Income: $\$ 20,000-\$ 39,999$ & 28.5 & 21.9 \\
HH Income: $\$ 40,000-\$ 74,999$ & 30.7 & 26.5 \\
HH Income: $>$ \$75,000 & 21.6 & 32.4 \\
\hline
\end{tabular}

Note: US population information obtained from Census Bureau estimates, 20102012. Since only individuals older than 18 are eligible to participate in our survey, age proportions are relative to the population over 18. US education measures are for the population 25 and older. US party affiliation information obtained from Gallop Politics.

and Asian individuals, adults in the 45-64 age range, more educated people, and Democrats. The sole place that our sample differs meaningfully from the US population is in high-income households. Approximately $22 \%$ of sample respondents report household income over $\$ 75,000$, while approximately $32 \%$ of the population US reports these incomes. ${ }^{6}$

\section{EMPIRICAL METHODS}

The goals of our empirical methods are to estimate WTP and valuation functions relating WTP to individual characteristics. Most generally, we model unobserved WTP as a latent variable for individual $i$ as $Y_{i}^{*}$, which may be related to $i$ 's socio-demographic and attitudinal features following $Y_{i}^{*}=x_{i}^{\prime} \beta+\varepsilon_{i}$. We assume errors, $\varepsilon_{i}$, are i.i.d. normally distributed.

Within this framework, one can assess valuation data like ours with several empirical methods, each with its own strengths and weaknesses. The simplest method is to use limited dependent variable models to analyze the single-bound dichotomous choice (SBDC) question (the first question) only. One advantage of SBDC approaches is that the first questions are especially easy for respondents to understand and answer. An additional advantage is that incentive compatibility is achieved with relatively weak assumptions on preferences (Carson, Groves, and List 2014). An alternative approach is to use DBDC approaches that analyze responses to the first valuation question and the follow-up question. ${ }^{7}$ The advantage of DBDC approaches is that they provide more information to researchers and may improve the efficiency of WTP estimates relative to single-bound questions (Hanemann, Loomis, and

6. If one assumes that marine protection is a normal good, an under-representation of high income households biases our WTP values conservatively downward.

7. Interval regression methods are a natural way to statistically analyze double-bounded valuation exercises, although Cameron and Quiggin (1994) and Alberini (1995) showed that bivariate probits impose fewer modeling assumptions and may be preferred under certain conditions. 
Kanninen 1991). The disadvantage is the incentive incompatibility and anchoring biases described in Whitehead (2002) and Kang, Haab, and Interis (2013).

We first examine results from interval regression models, since observed DBDC responses naturally fall into intervals. This model is readily interpretable, familiar to non-specialists, and yields conservative WTP estimates with our data. See Cameron and Trivedi (2005) for a formal treatment and Cawley (2008) or Viscusi, Huber, and Bell (2012) for recent applications. With interval regression, if an individual's WTP is known to lie in the interval $\left[\mathrm{y}_{1 \mathrm{i}}, \mathrm{y}_{2 \mathrm{i}}\right)$ because they voted "yes" at $\mathrm{y}_{1 \mathrm{i}}$ and "no" at $\mathrm{y}_{2 \mathrm{i}}$, then the likelihood contribution is $P\left(\gamma_{1 i} \leq Y_{i}^{*} \leq \gamma_{2 i}\right)=$ $P\left(\gamma_{1 i} \leq x_{i}^{\prime} \beta+\varepsilon_{i} \leq \gamma_{2 i}\right)$. For left-censored responses; i.e., when WTP falls in the range $\left(-\infty, \mathrm{y}_{\mathrm{Li}}\right)$, the likelihood contribution is $\operatorname{Pr}\left(Y_{i}^{*} \leq \gamma_{L i}\right)=\operatorname{Pr}\left(x_{i}^{\prime} \beta+\varepsilon_{i} \leq \gamma_{L i}\right)$. For right-censored responses; i.e., when WTP falls in the range $\left[\mathrm{y}_{\mathrm{Ri}}, \infty\right)$, the likelihood contribution is $\operatorname{Pr}\left(\gamma_{\mathrm{R} i} \leq Y_{i}^{*}\right)=$ $\operatorname{Pr}\left(\gamma_{R i} \leq x_{i}^{\prime} \beta+\varepsilon_{i}\right)$. Then, for left-censored observations $i \in L E F T$, interval observations $i \in$ $I N T$, right-censored observations $i \in R I G H T$, and standard normal $\operatorname{cdf} \Phi(\cdot)$, the log likelihood function is:

$$
\begin{aligned}
\ln L= & \sum_{i \in L E F T} \log \Phi\left(\frac{y_{L i}-x_{i}^{\prime} \beta}{\sigma}\right)+\sum_{i \in I N T} \log \left[\Phi\left(\frac{y_{2 i}-x_{i}^{\prime} \beta}{\sigma}\right)-\Phi\left(\frac{y_{1 i}-x_{i}^{\prime} \beta}{\sigma}\right)\right] \\
& +\sum_{i \in R I G H T} \log \left[1-\Phi\left(\frac{y_{R i}-x_{i}^{\prime} \beta}{\sigma}\right)\right] .
\end{aligned}
$$

Since the distribution of WTP can often be right skewed, we also repeat interval regression specifications using $\ln \left(Y_{i}^{*}\right)$ as the latent variable and $\ln \left(y_{1 i}\right), \ln \left(y_{2 i}\right), \ln \left(y_{R i}\right)$, and $\ln \left(y_{L i}\right)$ as bounds.

We also examine results from several alternative models. SBDC probits analyze responses to the first valuation question only. A "yes" vote occurs, $Y_{i}=1$, if $Y_{i}^{*}>A$, where $A$ is the bid amount. A "no" vote occurs otherwise. Constrained DBDC bivariate probits analyze responses to the first and second valuation questions. A "yes" vote occurs for question one, $Y_{i 1}=1$, if $Y_{i_{1}}^{*}>A_{1}$. A "no" vote occurs otherwise. A "yes" vote occurs for question two, $Y_{i 2}=1$, if $Y_{i_{2}}^{*}>A_{2}$. A "no" vote occurs otherwise. $\operatorname{Cov}\left[\varepsilon_{1}, \varepsilon_{2}\right]=\rho$, and all regression parameters are constrained to be equal across the first and second valuation equations. Since the distribution of WTP can often be right skewed, we repeat all probit and bivariate probits using $\ln \left(Y_{i}^{*}\right)$ as the latent variable.

\section{RESULTS}

\section{SURVEY RESPONSES}

Initial program costs in the final survey were about evenly distributed across sample respondents. Approximately $20.6,19.7,18.5,20.6$, and $20.6 \%$ of respondents were offered the program at an initial cost of $\$ 4, \$ 10, \$ 20, \$ 40$, and $\$ 80$, respectively. Figure 2 shows the probability of initial 'yes' and 'no' votes, conditional on these randomly assigned initial program costs. The likelihood that the respondent was willing to pay the first presented program cost declined monotonically as the proposed cost of the program increased, as predicted by demand theory.

Table 2 summarizes the complete set of possible response outcomes for each questionnaire version. The probability of yes-yes votes declined monotonically from over 55\% for $\$ 4 / \$ 8$ program cost offers to nearly $20 \%$ for $\$ 80 / \$ 160$ program cost offers. The probability of no-no votes increased monotonically from $15 \%$ for $\$ 4 / \$ 2$ program cost offers to over $39 \%$ 


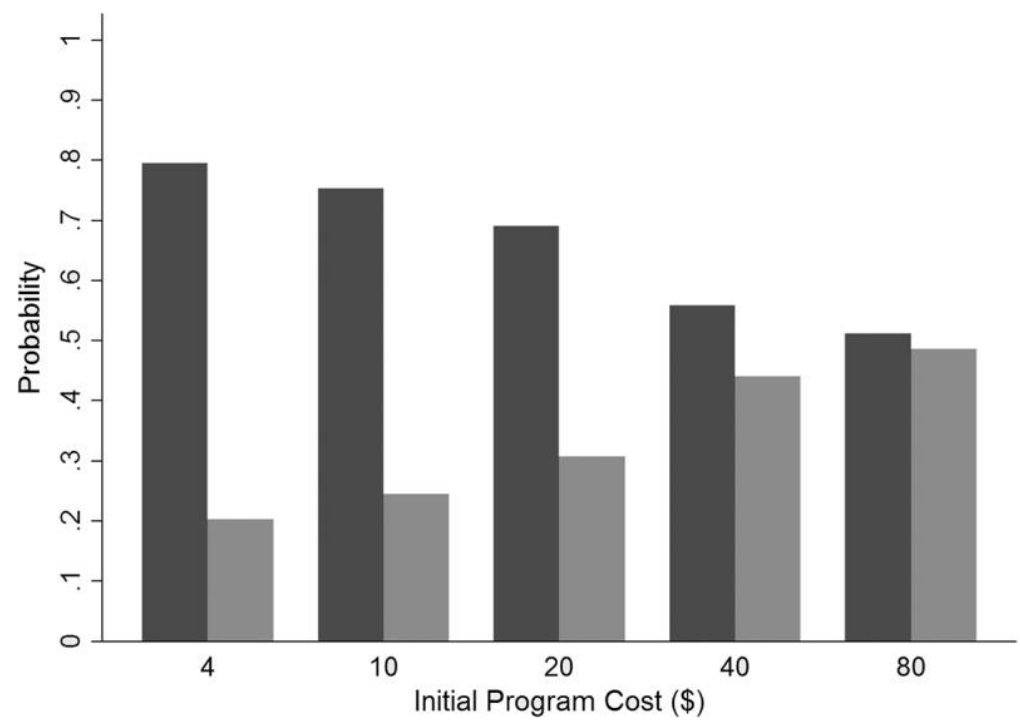

Figure 2. Probability of 'Yes' and 'No' Responses

Note: This chart represents the probability of 'yes' and 'no' responses, conditional on the randomly assigned questionnaire version. The darker left bars indicate the probability of an initial 'yes' and the lighter right bars indicate the probability of an initial 'no.' Note that the likelihood that the respondent is willing to pay the first proposed program cost declines monotonically as the cost of the program increases.

for $\$ 80 / \$ 40$ program cost offers. Directly interpreting yes-no and no-yes votes is difficult, but this information helps identify later formal estimates.

Figure 3 presents distributions of WTP and $\log$ WTP, where WTP values are approximated using the midpoint method. The left panel of figure 3 shows that the distribution of linear WTP was positively skewed with a long right tail. The right panel of figure 3 , however, shows that the distribution of log WTP appears symmetric and normally distributed. Valuation functions based on log WTP as the latent variable may more closely satisfy distributional assumptions.

Table 3 provides variable definitions and numerically summarizes response data.

Table 2. Dichotomous Program Response by Questionnaire Version

\begin{tabular}{lcccc}
\hline & Yes-Yes & Yes-No & No-Yes & No-No \\
\cline { 2 - 5 } Version & $(\%)$ & $(\%)$ & $(\%)$ & $(\%)$ \\
\hline A $(\$ 4, \$ 8, \$ 2)$ & 55.1 & 24.5 & 5.4 & 15.0 \\
B $(\$ 10, \$ 20, \$ 5)$ & 50.2 & 25.2 & 5.6 & 18.9 \\
C $(\$ 20, \$ 40, \$ 10)$ & 30.9 & 38.3 & 6.7 & 24.1 \\
D $(\$ 40, \$ 80, \$ 20)$ & 25.4 & 30.5 & 13.7 & 30.5 \\
E $(\$ 80, \$ 160, \$ 40)$ & 20.1 & 31.2 & 9.6 & 39.2 \\
\hline
\end{tabular}



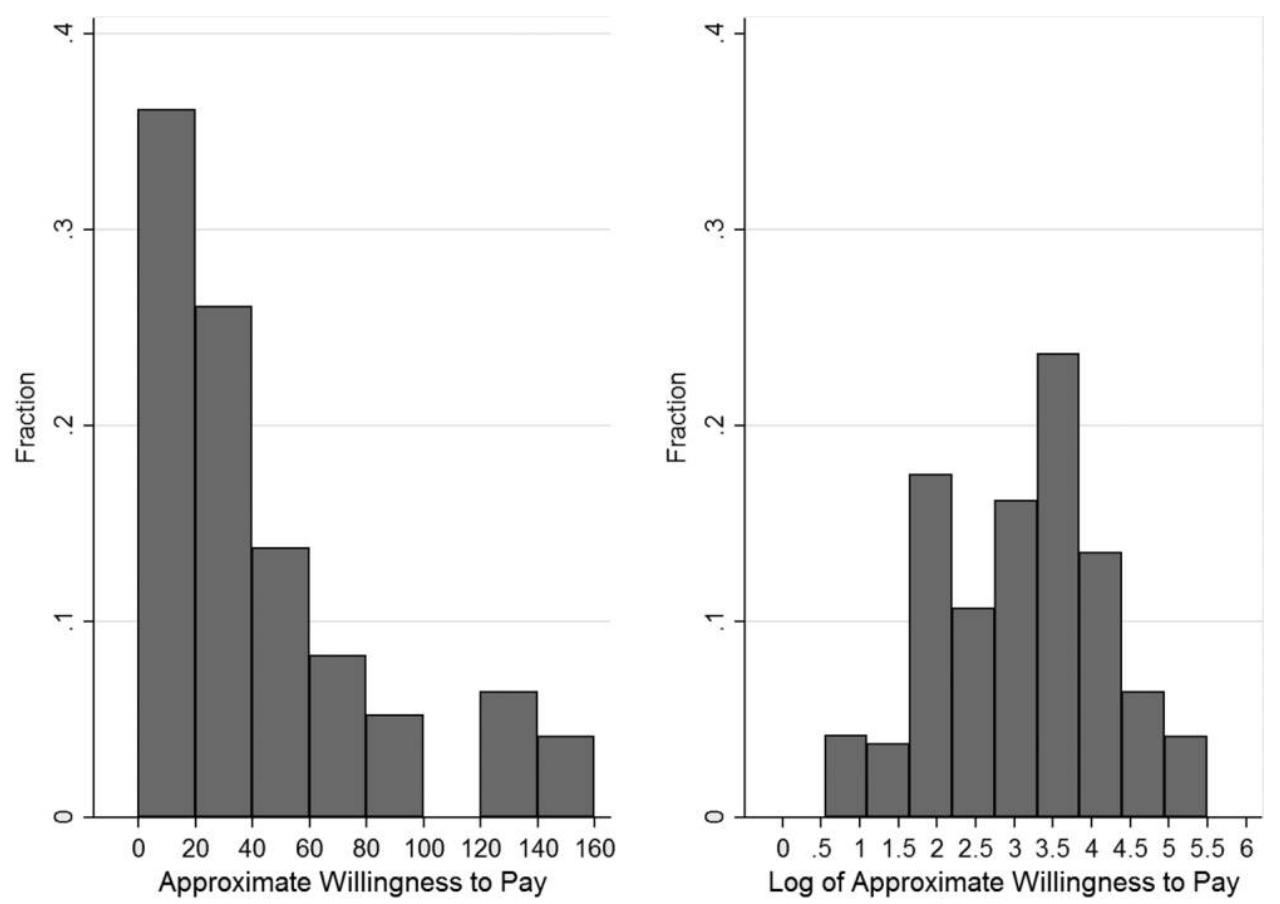

Figure 3. Distribution of Willingness to Pay Estimates

Note: These graphs depict distributions of WTP and log WTP. Since exact WTP is not observed in the dichotomous choice setting, a respondent's WTP value is approximated by the midpoint of the WTP interval when both interval endpoints are observed. A respondent's WTP value is approximated by the single known endpoint when only one interval endpoint is known. Note that the distribution of WTP appears rightskewed, while the distribution of log WTP appears approximately normally distributed

\section{ESTIMATION RESULTS}

Tables 4 and 5 present our core results from interval regressions, SBDC probits, and constrained double-bounded bivariate probits. In all specifications, WTP is statistically different from zero at the $1 \%$ level of significance. Average WTP in preferred specifications with full covariates ranges from approximately $\$ 35$ to $\$ 107$ per household per year. ${ }^{8}$

Significant determinants of WTP were generally the same across modeling choices. We interpret magnitudes in table 4 for brevity. In all specifications, younger respondents were willing to pay significantly more than older respondents. Table 4 panels (1) to (4) indicate that respondents aged 18 to 34 were willing to pay about $\$ 17$ to $\$ 18$ more than older respondents, on average. Table 4 panels (5) to (8) indicate that respondents aged 18 to 34 were willing to pay about 60 to $65 \%$ more than older respondents, on average. ${ }^{9}$ These results are consistent with a literature showing that WTP for environmental public goods seems to decline with age (Hoehn 1991; Whitehead and Blomquist 1991; Carson 1997). Households with lower incomes were willing to pay somewhat less than households with higher incomes, all else equal. Table 4

8. For interval regression results, we first calculate linear predictions. For linear WTP, we simply take the average. For log WTP, we account for log retransformation following Train (2003), Cameron and Trivedi (2005), and Viscusi, Huber, and Bell (2012). Here, we approximate average WTP as $\exp \left(\mu+\sigma^{2} / 2\right)$, where $\mu$ is the average predicted $\log$ WTP over individuals and $\sigma^{2}$ is the empirical variance of those predictions. In probits, median WTP is computed using nonlinear combinations of the parameters evaluated at the means of the explanatory variables.

9. The interpretation of coefficients on dummy variables in log-linear models is $100^{*}[\exp ($ beta $)-1]$ percent. 
Table 3. Definitions and Summary Statistics for Key Variables

\begin{tabular}{|c|c|c|c|}
\hline Characteristic & Description & Mean & Std. Dev. \\
\hline WTP & Approximate WTP (using midpoint method) & 38.12 & 39.56 \\
\hline WHITE & Race: White & 0.81 & 0.39 \\
\hline YOUNG & Age: $18-34$ & 0.29 & 0.45 \\
\hline FEMALE & Gender: Female & 0.51 & 0.50 \\
\hline COLLEGE & Education: Bachelor's deg. or higher & 0.34 & 0.47 \\
\hline LOW INCOME & HH Income: $<\$ 20,000$ & 0.19 & 0.39 \\
\hline DEMOCRAT & Party: Democrat & 0.36 & 0.48 \\
\hline REEF VISITOR & Experience: Has visited a coral reef & 0.26 & 0.44 \\
\hline ENVIRONMENT & Attitude: Nation should spend more on environmental protection & 0.47 & 0.47 \\
\hline BIODIVERSITY & $\begin{array}{l}\text { Attitude: Nation should spend more on the protection } \\
\text { of endangered species }\end{array}$ & 0.64 & 0.48 \\
\hline GULF STATE & Resident: TX, LA, MS, AL, FL & 0.19 & 0.39 \\
\hline SOUTHERN & Resident: US Census South Region & 0.35 & 0.48 \\
\hline WESTERN & Resident: US Census Western Region & 0.23 & 0.42 \\
\hline MIDWESTERN & Resident: US Census Midwestern Region & 0.21 & 0.40 \\
\hline MORE EFFECTIVE & $\begin{array}{l}\text { Belief: Marine reserve program will be extremely or very } \\
\text { effective for preventing further habitat degradation and } \\
\text { biodiversity loss }\end{array}$ & 0.32 & 0.47 \\
\hline LESS EFFECTIVE & $\begin{array}{l}\text { Belief: Marine reserve program will not be effective at } \\
\text { all or somewhat effective for preventing further habitat } \\
\text { degradation and biodiversity loss }\end{array}$ & 0.29 & 0.45 \\
\hline
\end{tabular}

results suggest respondents reporting household incomes below $\$ 20,000$ were willing to pay about $\$ 9$ to $\$ 10$ [panels (1)-(4)] or about 24 to $28 \%$ [panels (5)-(8)] less than higher-income respondents. We tried other approaches to modeling income effects, and as a general rule we found that statistically significant relationships between income and WTP were negative and driven by lower tails of the income distribution.

Respondents expressing pro-environment and pro-biodiversity attitudes were willing to pay significantly more than respondents not expressing those attitudes. Respondents believing the nation should spend more on environmental protection were willing to pay about $\$ 16$ to $\$ 23$ [panels (1)-(4)] or about 56 to 90\% [panels (5)-(8)] more than those with other opinions. Respondents believing the nation should spend more on biodiversity were willing to pay about $\$ 25$ to $\$ 30$ [panels (1)-(4)] or about 97 to $125 \%$ [panels (5)-(8)] more than those with other opinions. Visiting a reef in the past was always positively related to WTP, but not always significantly so. Table 4 results suggests visitors were willing to pay about $\$ 10$ to $\$ 11$ [panels (1)-(4)] or about 33 to $36 \%$ [panels (5)-(8)] more than those that hadn't visited a coral reef for recreational purposes. These latter results are consistent with the literature indicating that direct users may have higher WTP than passive users for environmental public goods (Carson and Mitchell 1993; Carson 1997).

Although the environmental valuation literature often finds that WTP declines with geographic distance from the good being valued (Sutherland and Walsh 1985; Hanley, Schläpfer, Spurgeon 2003), we find that residents of Gulf states (FL, AL, MS, LA, and TX) are willing to pay approximately the same amount for the marine reserve program as residents of other states, all else equal. Moreover, we find no consistent evidence that residents of the southern, western, or midwestern US are willing to pay significantly more or less than residents of an omitted area (predominantly the northeastern US). The lack of a distance-decay effect is con- 
Table 4. WTP and Determinants of WTP Estimation: Interval Regressions

\begin{tabular}{|c|c|c|c|c|c|c|c|c|}
\hline & \multicolumn{4}{|c|}{$\begin{array}{l}\text { Double-Bounded Dichotomous Choice } \\
\text { Interval Estimation in Levels }\end{array}$} & \multicolumn{4}{|c|}{$\begin{array}{l}\text { Double-Bounded Dichotomous Choice } \\
\text { Interval Estimation in Logs }\end{array}$} \\
\hline & (1) & (2) & (3) & (4) & (5) & (6) & (7) & (8) \\
\hline CONSTANT & $\begin{array}{l}46.72^{* * *} \\
(2.02)\end{array}$ & $\begin{array}{c}9.32 \\
(6.39)\end{array}$ & $\begin{array}{l}11.51 \\
(7.36)\end{array}$ & $\begin{array}{l}11.00 \\
(7.59)\end{array}$ & $\begin{array}{l}3.33^{* * *} \\
(0.05)\end{array}$ & $\begin{array}{l}2.18^{* * *} \\
(0.17)\end{array}$ & $\begin{array}{l}2.25^{* * *} \\
(0.20)\end{array}$ & $\begin{array}{l}2.24^{* * *} \\
(0.20)\end{array}$ \\
\hline WHITE & & $\begin{array}{c}0.31 \\
(5.11)\end{array}$ & $\begin{array}{l}-0.38 \\
(5.14)\end{array}$ & $\begin{array}{c}1.57 \\
(5.05)\end{array}$ & & $\begin{array}{c}0.10 \\
(0.13)\end{array}$ & $\begin{array}{c}0.08 \\
(0.14)\end{array}$ & $\begin{array}{c}0.14 \\
(0.13)\end{array}$ \\
\hline YOUNG & & $\begin{array}{l}17.90^{* * *} \\
(4.27)\end{array}$ & $\begin{array}{l}17.99^{* * *} \\
(4.25)\end{array}$ & $\begin{array}{l}16.54^{* * *} \\
(4.18)\end{array}$ & & $\begin{array}{l}0.49^{* * *} \\
(0.11)\end{array}$ & $\begin{array}{l}0.50^{* * *} \\
(0.11)\end{array}$ & $\begin{array}{l}0.46^{* * *} \\
(0.11)\end{array}$ \\
\hline FEMALE & & $\begin{array}{c}0.00 \\
(3.78)\end{array}$ & $\begin{array}{c}0.40 \\
(3.77)\end{array}$ & $\begin{array}{l}-1.21 \\
(3.74)\end{array}$ & & $\begin{array}{c}0.06 \\
(0.10)\end{array}$ & $\begin{array}{c}0.07 \\
(0.10)\end{array}$ & $\begin{array}{c}0.02 \\
(0.10)\end{array}$ \\
\hline COLLEGE & & $\begin{array}{l}-4.45 \\
(4.02)\end{array}$ & $\begin{array}{l}-4.54 \\
(4.03)\end{array}$ & $\begin{array}{l}-2.06 \\
(3.97)\end{array}$ & & $\begin{array}{l}-0.08 \\
(0.11)\end{array}$ & $\begin{array}{l}-0.08 \\
(0.11)\end{array}$ & $\begin{array}{l}-0.01 \\
(0.11)\end{array}$ \\
\hline LOW INCOME & & $\begin{array}{c}-9.16^{*} \\
(4.75)\end{array}$ & $\begin{array}{l}-9.34^{* *} \\
(4.75)\end{array}$ & $\begin{array}{c}-10.35^{* *} \\
(4.66)\end{array}$ & & $\begin{array}{c}-0.22^{*} \\
(0.13)\end{array}$ & $\begin{array}{c}-0.23^{*} \\
(0.13)\end{array}$ & $\begin{array}{l}-0.25^{* *} \\
(0.12)\end{array}$ \\
\hline DEMOCRAT & & $\begin{array}{c}6.17 \\
(4.06)\end{array}$ & $\begin{array}{c}5.78 \\
(4.06)\end{array}$ & $\begin{array}{c}4.61 \\
(4.01)\end{array}$ & & $\begin{array}{c}0.15 \\
(0.11)\end{array}$ & $\begin{array}{c}0.14 \\
(0.11)\end{array}$ & $\begin{array}{c}0.11 \\
(0.11)\end{array}$ \\
\hline ENVIRONMENT & & $\begin{array}{l}22.68^{* * *} \\
(4.16)\end{array}$ & $\begin{array}{l}22.40^{* * *} \\
(4.14)\end{array}$ & $\begin{array}{l}16.17^{* * *} \\
(4.11)\end{array}$ & & $\begin{array}{l}0.64^{* * *} \\
(0.11)\end{array}$ & $\begin{array}{l}0.63^{* * *} \\
(0.11)\end{array}$ & $\begin{array}{l}0.45^{* * *} \\
(0.11)\end{array}$ \\
\hline BIODIVERSITY & & $\begin{array}{l}29.86^{* * *} \\
(4.18)\end{array}$ & $\begin{array}{l}29.50^{* * *} \\
(4.17)\end{array}$ & $\begin{array}{l}25.21^{* * *} \\
(4.07)\end{array}$ & & $\begin{array}{l}0.81^{* * *} \\
(0.11)\end{array}$ & $\begin{array}{l}0.80^{* * *} \\
(0.11)\end{array}$ & $\begin{array}{l}0.68^{* * *} \\
(0.11)\end{array}$ \\
\hline REEF VISITOR & & $\begin{array}{l}11.16^{* *} \\
(4.44)\end{array}$ & $\begin{array}{l}11.31^{* *} \\
(4.44)\end{array}$ & $\begin{array}{l}10.31^{* *} \\
(4.38)\end{array}$ & & $\begin{array}{l}0.31^{* * *} \\
(0.11)\end{array}$ & $\begin{array}{l}0.31^{* * *} \\
(0.11)\end{array}$ & $\begin{array}{l}0.29^{* *} \\
(0.11)\end{array}$ \\
\hline GULF STATE & & $\begin{array}{c}3.20 \\
(4.80)\end{array}$ & & & & $\begin{array}{c}0.12 \\
(0.12)\end{array}$ & & \\
\hline MIDWESTERN & & & $\begin{array}{c}1.39 \\
(5.66)\end{array}$ & $\begin{array}{c}-1.49 \\
(5.58)\end{array}$ & & & $\begin{array}{c}0.03 \\
(0.15)\end{array}$ & $\begin{array}{c}-0.05 \\
(0.15)\end{array}$ \\
\hline SOUTHERN & & & $\begin{array}{c}-4.44 \\
(5.09)\end{array}$ & $\begin{array}{l}-7.18 \\
(5.04)\end{array}$ & & & $\begin{array}{l}-0.12 \\
(0.14)\end{array}$ & $\begin{array}{c}-0.19 \\
(0.13)\end{array}$ \\
\hline WESTERN & & & $\begin{array}{c}2.15 \\
(5.65)\end{array}$ & $\begin{array}{c}0.58 \\
(5.63)\end{array}$ & & & $\begin{array}{c}0.04 \\
(0.15)\end{array}$ & $\begin{array}{c}0.00 \\
(0.15)\end{array}$ \\
\hline MORE EFFECTIVE & & & & $\begin{array}{l}32.51^{* * *} \\
(4.64)\end{array}$ & & & & $\begin{array}{l}0.87^{* * *} \\
(0.12)\end{array}$ \\
\hline LESS EFFECTIVE & & & & $\begin{array}{c}-7.91^{\star} \\
(4.31)\end{array}$ & & & & $\begin{array}{c}-0.24^{\star *} \\
(0.12)\end{array}$ \\
\hline Observations & 1,526 & 1,526 & 1,526 & 1,526 & 1,526 & 1,526 & 1,526 & 1,526 \\
\hline Log Likelihood & $-2,248$ & $-2,159$ & $-2,158$ & $-2,118$ & $-2,068$ & $-1,973$ & $-1,972$ & $-1,931$ \\
\hline Predicted WTP & $\$ 46.72$ & $\$ 46.88$ & $\$ 46.85$ & $\$ 47.22$ & $\$ 28.07$ & $\$ 35.59$ & $\$ 35.56$ & $\$ 39.59$ \\
\hline
\end{tabular}

Note: ${ }^{* *},{ }^{* *}$, and ${ }^{*}$ indicate statistical significance at the 1,5 , and $10 \%$ levels, respectively.

sistent with several hypotheses, but results indicate that higher use values to those living in southern and Gulf states may be offset by possible reductions in important benefits from competing resource uses like oil and gas or commercial fishing. Or, respondent WTP motivations may more likely arise from passive use considerations than from direct use considerations.

Debriefing results suggest that passive use values largely drive our results. Sixty-two percent of respondents voting for the sanctuary program expressed a desire to protect marine biodiversity for future generations, suggesting bequest passive use value motivations. Fifty-two percent 


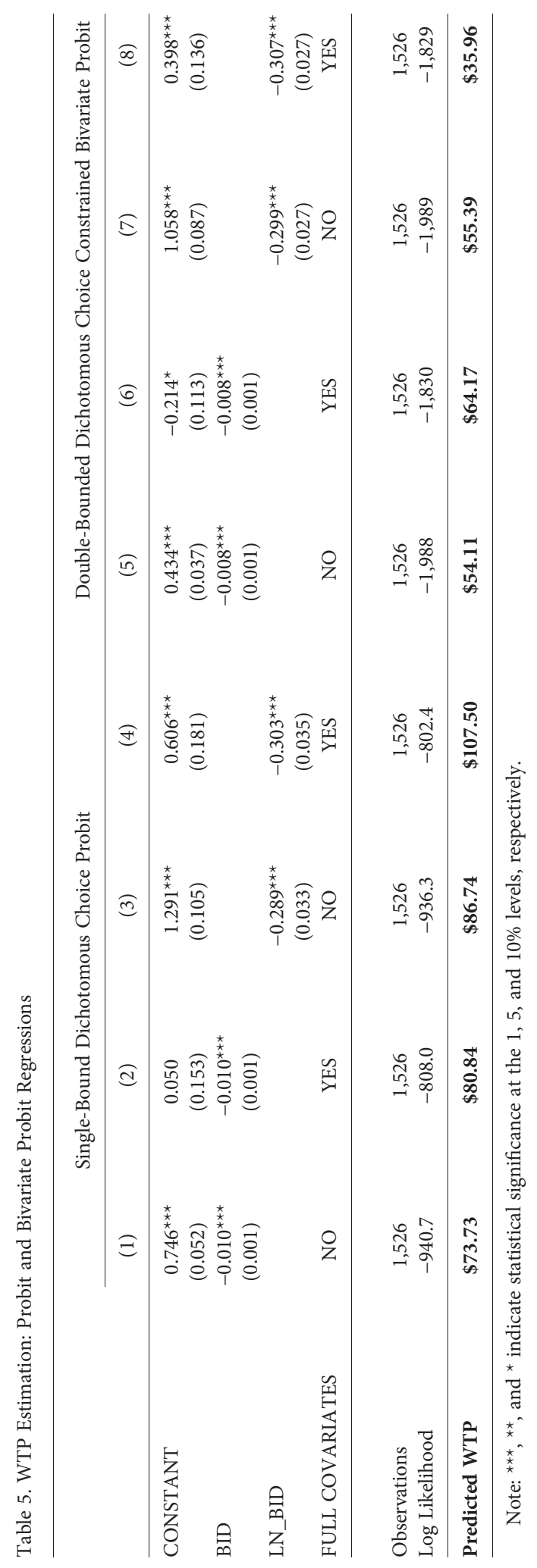

This content downloaded from 152.003.034.031 on February 03, 2016 06:36:29 AM All use subject to University of Chicago Press Terms and Conditions (http://www.journals.uchicago.edu/t-and-c). 
of respondents stated that the sanctuary program seemed like a good cause, $41 \%$ indicated that marine life has a right to exist independent of human use, 39\% expressed a desire for marine resources to be available for others, and 38\% expressed a moral duty to be a good steward of marine biodiversity. These responses suggest passive use incentives for WTP due, in part, to warm-glow motivations, existence values, vicarious consumption or paternalistic altruism motivations, and stewardship values. Forty-one percent of respondents expressed WTP because they visited the Gulf area, and 26\% stated they were willing to pay to protect the option to visit in the future.

\section{SENSITIVITY TO SCOPE}

Economic theory predicts that WTP should be sensitive to the quantity and quality of the good being valued and the attributes of the respondent. Although valuation studies now regularly perform credible scope tests and frequently reject a null of respondent scope insensitivity (Carson et al. 2013; Haab et al. 2013), a common recurring critique of stated preference surveys by non-practitioners is that stated WTP may not, in practice, satisfy scope requirements. The concern is that real-world respondents may not be sensitive to the amount of the valued good, the attributes of the valued good, or the characteristics of the individual (Hausman 2012; Carson 2012; Kling, Phaneuf, and Zhao 2012).

We find that WTP varies systematically with demographics and attitudes. Moreover, we find that respondents who believe the program will be extremely or very effective for preventing further habitat degradation and biodiversity loss were willing to pay substantially more than other respondents, all else equal. Beliefs about effectiveness were uncorrelated with WTP motivations, all else equal. Table 4 results suggest those believing the program would be highly effective were willing to pay about $\$ 33$ [panel (4)] or about 138\% [panel (8)] more than baseline respondents. The Carson et al. (2003) Exxon Valdez oil spill study interpreted similar findings as consistent with scope sensitivity. Individuals that believe they are paying for a program that averts more harm were willing to pay considerably more than individuals that believe they were paying for a program that averts less harm. We interpret this result loosely as a test of internal consistency. ${ }^{10}$

Our analysis uses a single sample approach because we had fixed survey dissemination resources and wanted to ensure sufficient statistical power to test a null hypothesis of zero WTP. However, we acknowledge that recent literature suggests that external scope tests with split samples randomly assigned to scenarios with more or less of the good provided would have been desirable with more resources (Carson et al. 2013; Haab et al. 2013). Johnson et al. (2012) provides an illustrative example.

\section{Other common concerns}

"Protest answers" will typically bias stated valuations downward. During debriefing, we asked those that voted against the program several questions designed to distinguish "protest no" motivations from "true zero value" motivations. We followed the recent literature, including

10. Although some authors interpret any exploration of scope sensitivity using self-reported variables as an 'internal scope test,' we avoid the term as other authors define internal scope tests as the specific case where the same sample in the same survey is given two different valuation questions with different quantities. 
Dziegielewska and Mendelsohn (2007); García-Llorente, Martín-López, and Montes (2011); and Groothuis and Whitehead (2002). We determined that those voting against the program who expressed opinions indicating that it was irrelevant, unimportant, a low social priority, or too expensive may represent "true zero values." We determined that those voting against the program who expressed opposition to new taxes of any kind, believed citizens should not bear costs of any kind, conveyed strong mistrust of public institutions, did not judge contributions to be helpful in this context, or expressed other related concerns may represent "protests no" responses. We then omitted the approximately $16 \%$ of respondents offering possible protest answers and replicated our analyses. Results are presented as online Appendix table A1. Predicted average WTP was higher by about one-fifth to one-third. Significant determinants of WTP remained unchanged.

A final common concern with stated preference valuation exercises is that respondents may have misunderstood the payment vehicle. In debriefing questions, we determined that some respondents thought they would have to pay the tax for one year rather than multiple years. This confusion could bias stated WTP upwards. We omitted the roughly $20 \%$ of respondents possibly misunderstanding the payment vehicle and replicated our analysis. Results are presented as online Appendix table A2. Predicted average WTP remained within $10 \%$. Significant determinants of WTP remained unchanged.

\section{DISCUSSION AND CONCLUSION}

In sum, we find that, on average, US residents expressed significantly positive values for boundary expansion at the Flower Garden Banks National Marine Sanctuary in the Gulf of Mexico. WTP estimates range from $\$ 35-\$ 107$ per household. Since the existing literature on WTP for marine reserves focuses on contexts outside of the Gulf of Mexico, specifically, and outside of the continental US, generally, we believe our results add to the existing literature. Most importantly, since we analyze a current, real-world public administration proposal, we believe our findings have the potential to inform domestic marine policy deliberations.

Our results are robust to several distinct empirical approaches and several specifications within each approach. Results were also robust to sensitivity experiments related to protest answers and scenario acceptance. Determinants of WTP were consistent with economic intuition. Younger respondents, respondents with higher incomes, respondents expressing proenvironment and pro-biodiversity attitudes, and reef recreationalists all expressed higher WTP than their counterparts. Contrary to expectations, we find no relationship between WTP and state of residence or distance to the reserve.

Few studies provide directly comparable results, but the findings in Bishop et al. (2011) may help provide perspective. Bishop et al. (2011) found that the average US household was willing to pay approximately $\$ 225$ per year for very sizeable changes in marine protection around the main Hawaiian Islands. Our conservative WTP figures were about 15 to $20 \%$ of the Bishop et al. (2011) figures, which seems reasonable given the more modest policy scope of our proposed expansion plan. In both studies, bequest motivations, stewardship ethics, existence values, or simple moral imperatives motivated substantial portions of WTP. Policy decisions related to marine biodiversity should, therefore, consider total economic value, as an emphasis on residents' and visitors' direct uses alone can seriously underestimate social values.

To put our results in further context, we aggregated our WTP outcomes. Following Office of Management and Budget recommendations for regulatory analysis, we assumed discount 
rates of 3,5 , and $7 \%$ (US OMB 2003). To make aggregate WTP figures directly comparable to published estimates of sanctuary expansion costs, we assumed a five-year planning horizon. This short planning horizon should provide conservative benefit estimates. We applied our lowest complete WTP estimate of \$35 per household to 114 million US households and found a total net present value of benefits of about $\$ 16.4$ to 18.3 billion over a five-year period. ${ }^{11}$ NOAA estimates of direct program costs over this same period are in the neighborhood of $\$ 15$ million (US Department of Commerce 2012). Significant indirect costs like foregone revenues to oil/gas and commercial fishing industries are unobserved, so a full benefit-cost analysis is beyond the scope of this study. Nevertheless, our results suggest that aggregate social benefits of marine biodiversity may be large in both absolute and relative terms.

\section{REFERENCES}

Alberini, A. 1995. "Efficiency vs. Bias of Willingness-to-Pay Estimates: Bivariate and Interval-Data Models." Lournal of Environmental Economics and Management 29(2):169-80.

Appletans, W., S. T. Ahyong, G. Anderson, M. V. Angel, T. Artois, N. Bailly, R. Bamber, A. Barber, I. Bartsch, A. Berta, M. Błażewicz-Paszkowyczm, P. Bock, G. Boxshall, C. B. Boyko, S. N. Brandão, R. A. Bray, N. L. Bruce, S. D. Cairns, T. Chan, L. Cheng, A. G. Collins, T. Cribb, M. Curini-Galletti, F. Dahdouh-Guebas, P. J. F. Davie, M. N. Dawson, O. De Clerck, W. Decock, S. De Grave, N. J. de Voogd, D. P. Domning, C. C. Emig, C. Erséus, W. Eschmeyer, K. Fauchald, D. G. Fautin, S. W. Feist, C. H. J. M. Fransen, H. Furuya, O. Garcia-Alvarez, S. Gerken, D. Gibson, A. Gittenberger, S. Gofas, L. Gómez-Daglio, D. P. Gordon, M. D. Guiry, F. Hernandez, B. W. Hoeksema, R. R. Hopcroft, D. Jaume, P. Kirk, N. Koedam, S. Koenemann, J. B. Kolb, R. M. Kristensen, A. Kroh, G. Lambert, D. B. Lazarus, R. Lemaitre, M. Longshaw, J. Lowry, E. Macpherson, L. P. Madin, C. Mah, G. Mapstone, P. A. McLaughlin, J. Mees, K. Meland, C. G. Messing, C. E. Mills, T. N. Molodtsova, R. Mooi, B. Neuhaus, P. K. L. Ng, C. Nielsen, J. Norenburg, D. M. Opresko, M. Osawa, G. Paulay, W. Perrin, J. F. Pilger, G. C. B. Poore, P. Pugh, G. B. Read, J. D. Reimer, M. Rius, R. M. Rocha, J. I. Saiz-Salinas, V. Scarabino, B. Schierwater, A. Schmidt-Rhaesa, K. E. Schnabel, M. Schotte, P. Schuchert, E. Schwabe, H. Segers, C. Self-Sullivan, N. Shenkar, V. Siegel, W. Sterrer, S. Stöhr, B. Swalla, M. L. Tasker, E. V. Thuesen, T. Timm, M. A. Todaro, X. Turon, S. Tyler, P. Uetz, J. van der Land, B. Vanhoorne, L. P. van Ofwegen, R. W. M. van Soest, J. Vanaverbeke, G. Walker-Smith, T. C. Walter, A. Warren, G. C. Williams, S. P. Wilson, M. J. Costello. 2012. “The Magnitude of Global Marine Species Diversity.” Current Biology 22 (23):2189-202.

Arrow, K., R. Solow, P. R. Portney, E. E. Leamer, R. Radner, and H. Schuman. 1993. "Report of the NOAA Panel on Contingent Valuation." Federal Register 58:4601-14.

Barbier, E. B. 2012. "Progress and Challenges in Valuing Coastal and Marine Ecosystem Services." Review of Environmental Economics and Policy 6(1):1-19.

Bishop, R. C., D. J. Chapman, B. J. Kanninen, J. A. Krosnick, B. Leeworthy, and N. F. Meade. 2011. “Total Economic Value for Protecting and Restoring Hawaiian Coral Reef Ecosystems: Final Report." NOAA Technical Memorandum CRCP 16, NOAA Office of National Marine Sanctuaries, Silver Spring, MD.

Börger, T. 2013. "Keeping up Appearances: Motivations for Socially Desirable Responding in Contingent Valuation Interviews.” Ecological Economics 87:155-65.

Cameron, A. C., and J. Quiggin. 1994. "Estimation using Contingent Valuation Data from a "Dichotomous Choice with Follow-Up" Questionnaire." Journal of Environmental Economics and Management 27(3):218-34.

11. NPV is calculated using finite annuity formulas. For example, for a rate of $5 \%, \mathrm{NPV}=\left(\left(114 \times 35\left(1-1 / 1.05^{5}\right)\right) / 0.05\right)$. 
Cameron, A. C., and P. K. Trivedi. 2005. Microeconometrics: Methods and Applications. New York: Cambridge University Press.

Carson, R. T. 1997. "Contingent Valuation: Theoretical Advances and Empirical Tests since the NOAA Panel." American Journal of Agricultural Economics 79(5):1501-07.

2012. "Contingent Valuation: A Practical Alternative When Prices Aren't Available." The Lournal of Economic Perspectives 26(4):27-42.

Carson, R. T., M. B. Conaway, W. M. Hanemann, R. C. Mitchell, and J. A. Krosnick. 2013. Valuing Oil Spill Prevention: A Case Study of California's Central Coast. New York: Kluwer Academic.

Carson, R. T., N. E. Flores, and N. F. Meade. 2001. "Contingent Valuation: Controversies and Evidence." Environmental and Resource Economics 19:173-210.

Carson, R. T., and T. Groves. 2007. "Incentive and Informational Properties of Preference Questions." Environmental and Resource Economics 37(1):181-210.

- 2011. "Incentive and Information Properties of Preference Questions: Commentary and Extensions." In International Handbook of Non-Market Environmental Valuation, ed. J. Bennett, 300-21. Northampton, MA: Edward Elgar.

Carson, R. T., T. Groves, and J. A. List. 2014. "Consequentiality: A Theoretical and Experimental Exploration of a Single Binary Choice." Journal of the Association of Environmental and Resource Economists 1(1/2):171-207.

Carson, R. T., and R. C. Mitchell. 1993. “The Value of Clean Water: The Public's Willingness to Pay for Boatable, Fishable, and Swimmable Quality Water.” Water Resources Research 29(7):2445-54.

Carson, R. T., R. C. Mitchell, M. Hanemann, R. J. Kopp, S. Presser, and P. A. Ruud. 2003. "Contingent Valuation and Lost Passive Use: Damages from the Exxon Valdez Oil Spill." Environmental and Resource Economics 25(3):257-86.

Cawley, J. 2008. "Contingent Valuation Analysis of Willingness to Pay to Reduce Childhood Obesity." Economics \& Human Biology 6(2):281-92.

Clark, J., J. Burgess, and C. M. Harrison. 2000. 'I Struggled with this Money Business: Respondents' Perspectives on Contingent Valuation.” Ecological Economics 33(1):45-62.

Coleman, F. C., P. B. Baker, and C. C. Koenig. 2004. "A Review of Gulf of Mexico Marine Protected Areas: Successes, Failures, and Lessons Learned.” Fisheries 29(2):10-21.

Costello M. J., M. Coll, R. Danovaro, P. Halpin, H. Ojaveer, and P. Miloslavich. 2010. "A Census of Marine Biodiversity Knowledge, Resources, and Future Challenges.” PLoS ONE 5(8):e12110.

Cruz, I., and R. J. McLaughlin. 2008. "Contrasting Marine Policies in the United States, Mexico, Cuba and the European Union: Searching for an Integrated Strategy for the Gulf of Mexico Region." Ocean \& Coastal Management 51(12):826-38.

Depondt, F., and E. Green. 2006. "Diver User Fees and the Financial Sustainability of Marine Protected Areas: Opportunities and Impediments." Ocean \& Coastal Management 49:188-202.

Dixon, J. A., L. F. Scura, and T. van't Hof. 1993. "Ecology and Microeconomics as 'Joint Products': The Bonaire Marine Park in the Caribbean." LATEN Dissemination Note \#6.

Dziegielewska, D. A., and R. Mendelsohn. 2007. "Does "No" mean "No"? A Protest Methodology." Environmental \& Resource Economics 38(1):71-87.

García-Llorente, M., B. Martín-López, and C. Montes. 2011. "Exploring the Motivations of Protestors in Contingent Valuation: Insights for Conservation Policies.” Environmental Science \& Policy 14(1):76-88.

Gleason, M., E. Fox, S. Ashcraft, J. Vasques, E. Whiteman, P. Serpa, E. Saarman, M. Caldwell, A. Frimodig, M. Miller-Henson, J. Kirlin, B. Ota, E. Pope, M. Weber, and K. Wiseman. 2013. "Designing a Network of Marine Protected Areas in California: Achievements, Costs, Lessons Learned, and Challenges Ahead." Ocean \& Coastal Management 74:90-101.

Groothuis, P. A., and J. C. Whitehead. 2002. "Does Don't Know Mean No? Analysis of 'Don't Know' Responses in Dichotomous Choice Contingent Valuation Questions.” Applied Economics 34(15):1935-40. 
Haab, T. C., M. G. Interis, D. R. Petrolia, and J. C. Whitehead. 2013. "From Hopeless to Curious? Thoughts on Hausman's "Dubious to Hopeless" Critique of Contingent Valuation." Applied Economic Perspectives and Policy 35(4):593-612.

Hall, D. C., J. V. Hall, and S. N. Murray. 2002. "Contingent Valuation of Marine Protected Areas: Southern California Rocky Intertidal Ecosystems.” Natural Resource Modeling 15(3):335-68.

Hanemann, M., J. Loomis, and B. Kanninen. 1991. "Statistical Efficiency of Double-Bounded Dichotomous Choice Contingent Valuation." American Journal of Agricultural Economics 73(4):1255-63.

Hanley, N., F. Schläpfer, and J. Spurgeon. 2003. "Aggregating the Benefits of Environmental Improvements: Distance-Decay Functions for Use and Non-Use Values.” Lournal of Environmental Management 68(3):297-304.

Hausman, J. 2012. "Contingent Valuation: From Dubious to Hopeless." The Journal of Economic Perspectives 26(4):43-56.

Hoehn, J. P. 1991. "Valuing the Multidimensional Impacts of Environmental Policy: Theory and Methods." American Journal of Agricultural Economics 73(2):289-99.

Holland, D. S., and R. J. Brazee. 1996. "Marine Reserves for Fisheries Management." Marine Resource Economics 11(3):157-71.

Hwang, J., D. R. Petrolia, and M. G. Interis. 2014. "Consequentiality and Opt-out Responses in Stated Preference Surveys.” Agricultural and Resource Economics Review 43(3):471-88.

Internet World Stats. 2011. "United States Internet Usage, Broadband and Telecommunications Reports." http://www.internetworldstats.com/am/us.htm.

Ivehammer, P. 2009. “The Payment Vehicle Used in CV Studies of Environmental Goods Does Matter." Journal of Agricultural and Resource Economics 34(3):450-63.

Johnson, B. K., J. C. Whitehead, D. S. Mason, and G. J. Walker. 2012. "Willingness to Pay for Downtown Public Goods Generated by Large, Sports-Anchored Development Projects: The CVM Approach." City, Culture and Society 3(3):201-08.

Johnston, R. J. 2006. "Is Hypothetical Bias Universal? Validating Contingent Valuation Responses Using a Binding Public Referendum.” Iournal of Environmental Economics and Management 52(1):469-81.

Kahui, V., and W. R. J. Alexander. 2008. "A Bioeconomic Analysis of Marine Reserves for Paua (Abalone) Management at Stewart Island, New Zealand.” Environmental \& Resource Economics 40(3):339-67.

Kang, H., T. C. Haab, and M. G. Interis. 2013. "Identifying Inconsistent Responses in Dichotomous Choice Contingent Valuation with Follow-Up Questions.” Resource and Energy Economics 35(3):396-411.

Kim, G. S., D. R. Petrolia, and M. G. Interis. 2012. "A Method for Improving Welfare Estimates from Multiple-Referendum Surveys.” Journal of Agricultural \& Resource Economics 37(2):289-300.

Kling, C. L., D. J. Phaneuf, and J. Zhao. 2012. "From Exxon to BP: Has Some Number Become Better than No Number?" The Journal of Economic Perspectives 26(4):3-26.

Landry, C. E., P. Hindsley, O. Bin, J. B. Kruse, J. Whitehead, and K. R. Wilson. 2011. "Weathering the Storm: Measuring Household Willingness-to-Pay for Risk-Reduction in Post-Katrina New Orleans." Southern Economic Journal 77(4):991-1013.

Lindhjem, H., and S. Navrud. 2011. "Are Internet Surveys an Alternative to Face-to-Face Interviews in Contingent Valuation?” Ecological Economics 70(9):1628-37.

Mathieu, L. F., I. H. Langford, and W. Kenyon. 2003. "Valuing Marine Parks in a Developing Country: A Case Study of the Seychelles." Environment and Development Economics 8(02):373-90.

McVittie, A., and D. Moran. 2010. "Valuing the Non-Use Benefits of Marine Conservation Zones: An Application to the UK Marine Bill." Ecological Economics 70(2):413-24.

National Ocean Service. 2011. "The Gulf of Mexico at a Glance: A Second Glance." Washington, DC: US Department of Commerce.

Nielsen, J. S. 2011. "Use of the Internet for Willingness-to-Pay Surveys. A Comparison of Face-to-Face and Web-Based Interviews." Resource and Energy Economics 33(1):119-29. 
Peters, H., and J. P. Hawkins. 2009. "Access to Marine Parks: A Comparative Study in Willingness to Pay." Ocean Coastal Management 52(3):219-28.

Petrolia, D. R., M. G. Interis, and J. Hwang. 2014. “America's Wetland? A National Survey of Willingness to Pay for Restoration of Louisiana's Coastal Wetlands.” Marine Resource Economics 29(1):1737.

Petrolia, D. R., and T. G. Kim. 2009. "What are Barrier Islands Worth? Estimates for Willingness to Pay for Restoration." Marine Resource Economics 24(2):131-46.

- 2011. "Preventing Land Loss in Coastal Louisiana: Estimates of WTP and WTA." Lournal of Environmental Management 92(3):859-65.

Ransom, K. P., and S. C. Mangi. 2010. "Valuing Recreational Benefits of Coral Reefs: The Case of Mombasa Marine National Park and Reserve, Kenya." Environmental Management 45(1):145-54.

Reid-Grant, K., and M. G. Bhat. 2009. "Financing Marine Protected Areas in Jamaica: An Exploratory Study." Marine Policy 33(1):128-36.

Ressurreição, A., J. Gibbons, T. P. Dentinho, M. Kaiser, R. S. Santos, and G. Edwards-Jones. 2011. "Economic Valuation of Species Loss in the Open Sea." Ecological Economics 70(4):729-39.

Ritchie, K. B., and B. D. Keller, ed. 2008. "A Scientific Forum on the Gulf of Mexico: The Islands in the Stream Concept.” Marine Sanctuaries Conservation Series NMSP-07-xx. US Department of Commerce, National Oceanic and Atmospheric Administration, National Marine Sanctuary Program, Silver Spring, MD.

Sanchirico, J. N., and J. E. Wilen. 2001. "Bioeconomic of Marine Reserve Creation.” Journal of Environmental Economics and Management 42(3):257-76.

Schuhmann, P. W., J. F. Casey, J. A. Horrocks, and H. A. Ozenford. 2013. “Recreational SCUBA Divers' Willingness to Pay for Marine Biodiversity in Barbados." Lournal of Environmental Management 121: 29-36.

Smith, M. D., J. Lynham, J. N. Sanchirico, and J. A. Wilson. 2010. "Political Economy of Marine Reserves: Understanding the Role of Opportunity Costs.” PNAS 107(43):18300-305.

Smith, M. D., J. Zhang, and F. C. Coleman. 2007. "Structural Modeling of Marine Reserves with Bayesian Estimation.” Marine Resource Economics 22(2):121-36.

Spash, C. L. 2002. "Informing and Forming Preferences in Environmental Valuation: Coral Reef Biodiversity." Iournal of Economic Psychology 23(5):665-87.

Subade, R. F. 2005. "Valuing Biodiversity Conservation in a World Heritage Site: Citizens' Non-Use Values for Tubbataha Reefs National Marine Park, Philippines.” Report No. 2005-RR4. Economy and Environment Program for Southeast Asia (EEPSEA), Singapore.

Suman, D., M. Shivlani, and J. W. Milon. 1999. "Perceptions and Attitudes Regarding Marine Reserves: A Comparison of Stakeholder Groups in the Florida Keys National Marine Sanctuary.” Ocean \& Coastal Management 42(12):1019-40.

Sutherland, R. J., and R. G. Walsh. 1985. "Effect of Distance on the Preservation of Water Quality." Land Economics 61(3):281-91.

Thur, S. M. 2010. "User Fees as Sustainable Financing Mechanisms for Marine Protected Areas: An Application to the Bonaire National Marine Park." Marine Policy 34(1):63-9.

Thurston, H. W. 2006. "Non-market Valuation in the Internet." In Handbook on Contingent Valuation, ed. A. Alberini and J. R. Kahn, 265-84. Northampton, MA: Edward Elgar Publishing.

Togridou, A., T. Hovardas, and J. D. Pantis. 2006. "Determinants of Visitors' Willingness to Pay for the National Marine Park of Zakythnos, Greece.” Ecological Economics 60(1):308-19.

Train, K. 2003. Discrete Choice Methods with Simulation. New York: Cambridge University Press.

US Department of Commerce, National Oceanic and Atmospheric Administration, and Office of National Marine Sanctuaries. 2012. "Flower Garden Banks National Marine Sanctuary Final Management Plan.” Washington, DC: US Department of Commerce. 
US EPA, Mississippi River Gulf of Mexico Watershed Nutrient Task Force. 2011. "Moving Forward on Gulf Hypoxia: Annual Report 2011.” Washington, DC.

US OMB. 2003. "Circular A-4, Memo to Heads of Executive Agencies and Establishments, Subject: Regulatory Analysis." Washington, DC.

Uyarra, M. C., J. A. Gill, and I. M. Cote. 2010. "Charging for Nature: Marine Park Fees and Management from a User Perspective.” Ambio 39(7):515-23.

Viscusi, W. K., J. Huber, and J. Bell. 2012. "Heterogeneity in Values of Morbidity Risks from Drinking Water." Environmental and Resource Economics 52(1):23-48.

Vossler, C. A., and G. L. Poe. 2011. "Consequentiality and Contingent Values: An Emerging Paradigm." In The International Handbook on Non-Market Environmental Valuation, ed. J. Bennett, 122-41. Northampton, MA: Edward Elgar Publishing.

Whitehead, J. C. 2002. "Incentive Incompatibility and Starting-Point Bias in Iterative Valuation Questions." Land Economics 78(2):285-97.

_ 2006. "A Practitioner's Primer on the Contingent Valuation Method." In Handbook on Contingent Valuation, ed. A. Alberini and J. R. Kahn, 66-91. Northampton, MA: Edward Elgar Publishing.

Whitehead, J. C., and G. C. Blomquist. 1991. "Measuring Contingent Values for Wetlands: Effects of Information about Related Environmental Goods." Water Resources Research 27(10):2523-31. 